\title{
MRS Membership Approves New Constitution
}

On July 19, the Materials Research Society began operating under a revised constitution. By an overwhelming majority, MRS membership approved the revisions, which were submitted to them for approval in June.

The intent of the new constitution was to restructure the governance of the Society to better enable the Board of Directors (formerly called the Council) to focus on long-range and strategic issues and provide clear direction to action committees. As MRS President Alex King said, the constitutional changes will "ensure that MRS will continue to be strategic, responsive, and world-leading in all of its ventures, even as it grows and as its environment changes."

There will be three standing Board committees-Planning, Operational Oversight, and External Relations and Volunteer Involvement. Each member of the Board will sit on one of these three. A Governance Committee, comprising the chairs of the three standing committees and the officers, will oversee the work of these committees.

Under the new structure, the action committees will be empowered to a greater degree than before and will be encouraged to take initiative in realizing the goals set by the Board of Directors.

In summary, changes resulting from the new constitution are:
- Council will be known as the Board of Directors.

- Elected officers will be the Vice President (who automatically assumes the presidency in the following year) and the Secretary; the Treasurer position will be filled by Board appointment.

- The Board will include 15 elected Directors with staggered three-year terms, as was previously the case with Councillors. Additionally, the Board may appoint up to three additional Directors who are not elected by the membership.

- The Executive Committee has been eliminated.
M|R/S 